Article

\title{
Chemical Constituents from the Flower of Hosta plantaginea with Cyclooxygenases Inhibition and Antioxidant Activities and Their Chemotaxonomic Significance
}

\author{
Li Yang ${ }^{1}$, Shu-Tai Jiang ${ }^{2}$, Qin-Guang Zhou ${ }^{3}$, Guo-Yue Zhong ${ }^{3}$ and Jun-Wei He ${ }^{3, *}$ \\ 1 Key Laboratory of Modern Preparation of TCM, Jiangxi University of Traditional Chinese Medicine, \\ Ministry of Education, Nanchang 330004, China; yangli07971@163.com \\ 2 Institute of Traditional Chinese Medicine and Natural Products, College of Pharmacy, Jinan University, \\ Guangzhou 510632,China; vstjiang@stu2014.jnu.edu.cn \\ 3 Research Center of Natural Resources of Chinese Medicinal Materials and Ethnic Medicine, \\ Jiangxi University of Traditional Chinese Medicine, Nanchang 330004, China; \\ qingguangzhou58@gmail.com (Q.-G.Z.); zgy1037@163.com (G.-Y.Z.) \\ * Correspondence: hjwjn2008@163.com; Tel.: +86-0791-87118873
}

Received: 29 September 2017; Accepted: 25 October 2017; Published: 26 October 2017

\begin{abstract}
Two new phenolic glucosides, hostaflavanone A (1) and anti-1-phenylpropane-1,2-diol-2-O$\beta$-D-glucopyranoside (2), together with six known compounds, anti-1-phenylpropane-1,2-diol (3), phenethyl-O- $\beta$-D-glucopyranoside (4), phenethanol- $\beta$-D-gentiobioside (5), phenethyl-O-rutinoside (6), (1S, 3S)-1-methyl-1,2,3,4-tetrahydro- $\beta$-carboline-3-carboxylic acid (7), and (1R, 3S)-1-methyl1,2,3,4-tetrahydro- $\beta$-carboline-3-carboxylic acid (8), were isolated from the flower of Hosta plantaginea, and their structures were elucidated by nuclear magnetic resonance (NMR), high resolution electrospray ionization mass spectroscopy (HRESIMS), and circular dichroism (CD) analyses. The cyclooxygenases (COX-1 and COX-2) inhibition and antioxidant activities of compounds 1 and 4-6 were investigated, and they showed moderate cyclooxygenases inhibition activities. Moreover, only compound 1 exhibited moderate antioxidant activity, with an $\mathrm{IC}_{50}$ value of $83.2 \mu \mathrm{M}$, while 4-6 showed insignificant activity with $\mathrm{IC}_{50}$ values of 282,257 , and $275 \mu \mathrm{M}$, respectively. This is the first report of compounds $\mathbf{3}$ and 5-8 from the Liliaceae family. The chemotaxonomic significance of the isolated compounds was also summarized.
\end{abstract}

Keywords: Hosta plantaginea; chemical constituents; cyclooxygenase inhibition; antioxidant; chemotaxonomics

\section{Introduction}

The genus Hosta belongs to the family Liliaceae, with approximately 40 species distributed in the temperate and subtropical zones of Asia [1]. The ethnopharmacological and chemotaxonomic significance of the genus Hosta led us to investigate the chemical constituents of one of its species, namely Hosta plantaginea (Lam.) Aschers, which was a medicinal and ornamental plant in China. Its flowers are commonly used as a traditional Mongolian medicine in China for the treatment of sore throat, mute, lung heat, and toxic heat [2]. Previous phytochemical studies on H. plantaginea afforded structurally-diverse and biologically-active compounds, such as steroidals, alkaloids, flavonoids, and monoterpenes, some of them showed potent anti-inflammatory, cytotoxic, antibacterial, antiviral, and antioxidant activities [3-8]. These facts encouraged us to investigate new and bioactive secondary metabolites from $H$. plantaginea. In the present study, we had isolated and elucidated two new phenolic glucosides (1 and 2), and six known ones from the ethanol extract of the flowers of $H$. plantaginea. 
Herein, we report the isolation, structure elucidation, as well as the cyclooxygenases' (COX-1 and COX-2) inhibition and antioxidant activities of compounds 1-8 (Figure 1). This is the first report of compounds $\mathbf{3}$ and 5-8 from the Liliaceae family. The chemotaxonomic significance of the isolated compounds was also summarized.

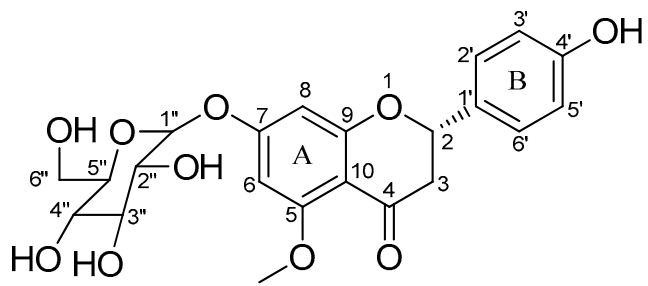<smiles>[R][R]([R])[CH]OC(C)[C@@H](O)c1ccccc1</smiles>

1
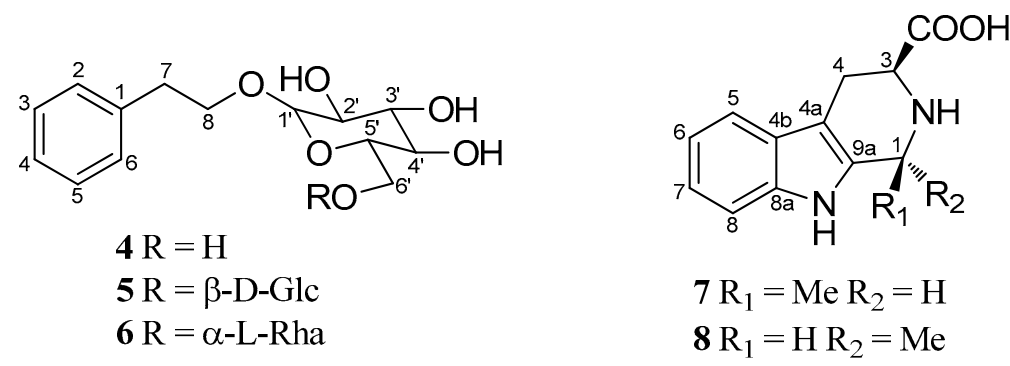

Figure 1. Chemical structures of compounds 1-8.

\section{Results and Discussion}

\subsection{Identification of Compounds $\mathbf{1}-\mathbf{8}$}

Compound 1 was isolated as a yellow oil, $[\alpha]_{D}^{25}-48.2\left(c 1.0, \mathrm{CH}_{3} \mathrm{OH}\right)$, had a molecular formula of $\mathrm{C}_{22} \mathrm{H}_{24} \mathrm{O}_{10}$ on the basis of the HR-ESI-MS $\left(m / z 449.14498\right.$, calcd. $\left.449.14422[\mathrm{M}+\mathrm{H}]^{+}\right)$. The UV absorption bands at $\lambda_{\max } 281$ and $322 \mathrm{~nm}$ suggested the presence of a flavanone skeleton in 1 [9]. The ${ }^{1} \mathrm{H}-\mathrm{NMR}$ spectrum of $\mathbf{1}$ (Table 1, see the Supplementary Materials) exhibited a pair of meta-positioned aromatic protons at $\delta_{\mathrm{H}} 6.28$ and 6.24 (each, $1 \mathrm{H}, \mathrm{d}, J=2.5 \mathrm{~Hz}$ ) in ring $\mathrm{A}$, an $\mathrm{AA}^{\prime} \mathrm{XX}^{\prime}$ coupling system at $\delta_{\mathrm{H}} 7.30$ and 6.79 (each, $2 \mathrm{H}, \mathrm{d}, J=8.4 \mathrm{~Hz}$ ) in ring $\mathrm{B}$. The ${ }^{13} \mathrm{C}-\mathrm{NMR}$ spectrum of 1 (Table 1) combined with DEPT 135 spectrum displayed 22 resonances for a carbonyl carbon $\left(\delta_{\mathrm{C}}\right.$ 188.3), 12 aromatic carbons $\left(\delta_{C} 164.1,163.3,161.7,157.7,129.1,128.3,128.3,115.2,115.2,106.1,96.1\right.$, and 94.0), one oxymethine carbon $\left(\delta_{C} 78.3\right)$, one methoxyl group $\left(\delta_{C} 55.9\right)$, one methylene carbon $\left(\delta_{C}\right.$ $44.7)$, and a D-glucosyl moiety $\left(\delta_{C} 99.7,77.2,76.5,73.1,69.7\right.$, and 60.7$)$, which was supported by the result of the acid hydrolysis and HPLC analysis. Based on the above evidence, the aglycone of $\mathbf{1}$ was identified as flavanone. Additionally, the configuration of the anomeric carbon was deduced to be $\beta$ based on the coupling constant of the anomeric proton $\left(\mathrm{H}-1^{\prime \prime} 7.8 \mathrm{~Hz}\right)$. The glucosidic linkage was established by the HMBC correlation (Figure 2$)$ between $\mathrm{H}-1^{\prime \prime}\left(\delta_{\mathrm{H}} 4.99\right)$ and $\mathrm{C}-7\left(\delta_{\mathrm{C}} 163.3\right)$, indicating that the glucosyl moiety was attached to $\mathrm{C}-7$. Moreover, the methoxyl group was located at $\mathrm{C}-5$ by the HMBC correlation from $5-\mathrm{OCH}_{3}\left(\delta_{\mathrm{H}} 3.78\right)$ to $\mathrm{C}-5\left(\delta_{\mathrm{C}} 161.7\right)$. With the aid of ${ }^{1} \mathrm{H}-{ }^{1} \mathrm{H}$ COSY, HSQC, and HMBC correlations allowed the established the planar structure and assigned all the ${ }^{1} \mathrm{H}$ - and ${ }^{13} \mathrm{C}-\mathrm{NMR}$ signals of 1, which was isolated from Prunus cerasoides and named puddumin A [10]. However, only incomplete 1D-NMR data of $\mathbf{1}$ was given in the literature 10, which was also differ greatly from our data (Table 1). The electronic circular dichroism (CD) spectrum of $\mathbf{1}$ (Figure 3) showed a negative Cotton effect at $282 \mathrm{~nm}\left(\pi \rightarrow \pi^{*}\right.$ electronic transition) and a positive Cotton effect at $338 \mathrm{~nm}\left(\mathrm{n} \rightarrow \pi^{*}\right.$ electronic transition), suggesting that the absolute configuration at C-2 was $S[9,11]$. Thus, the structure of 1 was fully elucidated, and it was named hostaflavanone A. 


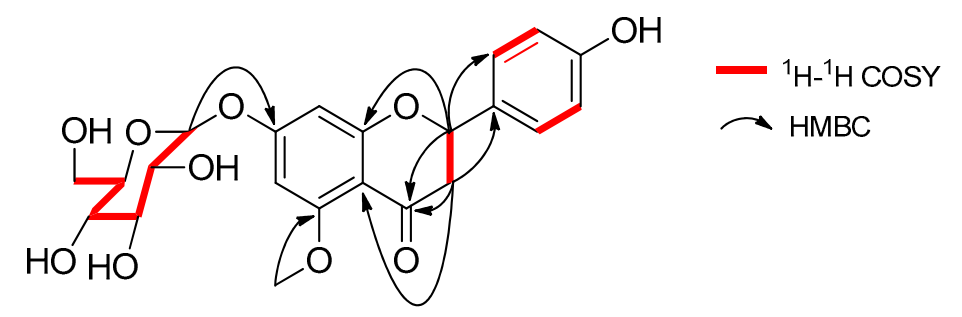

Figure 2. Selected ${ }^{1} \mathrm{H}_{-}{ }^{1} \mathrm{H}$ COSY and HMBC correlations of $\mathbf{1}$.

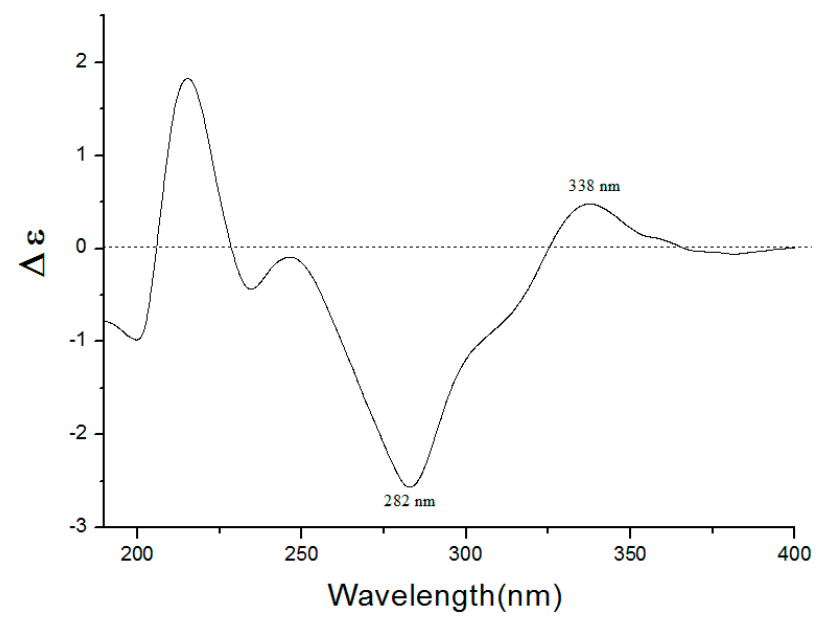

Figure 3. $\mathrm{CD}$ spectrum of compound 1 in $\mathrm{CH}_{3} \mathrm{OH}$.

Table $1 .{ }^{13} \mathrm{C}$ - and ${ }^{1} \mathrm{H}-\mathrm{NMR}$ data for compounds $\mathbf{1}$ and puddumin A in DMSO- $d_{6}(\delta$ in ppm).

\begin{tabular}{|c|c|c|c|c|}
\hline \multirow{2}{*}{ Position } & \multicolumn{2}{|r|}{1} & \multicolumn{2}{|c|}{ Puddumin A } \\
\hline & $\delta_{\mathrm{C}}$ & $\delta_{\mathrm{H}}(J$ in $\mathrm{Hz})$ & $\delta_{\mathrm{C}}$ & $\delta_{\mathrm{H}}(J$ in $\mathrm{Hz})$ \\
\hline 2 & 78.3 & $5.40(1 \mathrm{H}, \mathrm{m})$ & 78.3 & $6.15(1 \mathrm{H}, \mathrm{s})$ \\
\hline 3 & 44.7 & $\begin{array}{c}3.07(1 \mathrm{H}, \mathrm{dd}, J=16.3 / 12.8) \\
2.57(1 \mathrm{H}, \mathrm{dd}, J=16.3 / 2.5)\end{array}$ & 44.5 & $\begin{array}{c}3.30(1 \mathrm{H}, \mathrm{d}, J=2) \\
2.70(1 \mathrm{H}, \mathrm{s})\end{array}$ \\
\hline 4 & 188.3 & $-a$ & 192.4 & $-a$ \\
\hline 5 & 161.7 & $-a$ & 159.9 & $-{ }^{\mathrm{a}}$ \\
\hline 6 & 94.0 & $6.28(1 \mathrm{H}, \mathrm{d}, J=2.5)$ & 93.7 & $6.40(1 \mathrm{H}, \mathrm{d}, J=2)$ \\
\hline 7 & 163.3 & $-a$ & 165.6 & $-a$ \\
\hline 8 & 96.1 & $6.24(1 \mathrm{H}, \mathrm{d}, J=2.5)$ & 95.1 & $6.78(1 \mathrm{H}, \mathrm{d}, J=2)$ \\
\hline 9 & 164.1 & $-a$ & 165.1 & $-a$ \\
\hline 10 & 106.1 & $-a$ & 106.5 & $-a$ \\
\hline $1^{\prime}$ & 129.1 & $-\mathrm{a}$ & 126.0 & $-{ }^{\mathrm{a}}$ \\
\hline $2^{\prime}, 6^{\prime}$ & 128.3 & $7.30(2 \mathrm{H}, \mathrm{d}, J=8.4)$ & 130.8 & $7.65(2 \mathrm{H}, \mathrm{d}, J=9)$ \\
\hline $3^{\prime}, 5^{\prime}$ & 115.2 & $6.79(2 \mathrm{H}, \mathrm{d}, J=8.4)$ & 115.9 & $6.83(2 \mathrm{H}, \mathrm{d}, J=9)$ \\
\hline $4^{\prime}$ & 157.7 & $-a$ & 159.6 & $-a$ \\
\hline $1^{\prime \prime}$ & 99.7 & $4.99(1 \mathrm{H}, \mathrm{d}, J=7.8)$ & 100.3 & $-b$ \\
\hline $2^{\prime \prime}$ & 73.1 & $3.23(1 \mathrm{H}, \mathrm{m})$ & 73.3 & $-b$ \\
\hline $3^{\prime \prime}$ & 76.5 & $3.28(1 \mathrm{H}, \mathrm{m})$ & 76.8 & $-b$ \\
\hline $4^{\prime \prime}$ & 69.7 & $3.14(1 \mathrm{H}, \mathrm{m})$ & 69.6 & $-b$ \\
\hline $5^{\prime \prime}$ & 77.2 & $3.39(1 \mathrm{H}, \mathrm{m})$ & 77.5 & $-b$ \\
\hline $6^{\prime \prime}$ & 60.7 & $\begin{array}{l}3.68(1 \mathrm{H}, \mathrm{m}) \\
3.43(1 \mathrm{H}, \mathrm{m})\end{array}$ & 60.6 & $\mathrm{~b}$ \\
\hline $5-\mathrm{OCH}_{3}$ & 55.9 & $3.78(3 \mathrm{H}, \mathrm{s})$ & 55.5 & $3.80(3 \mathrm{H}, \mathrm{s})$ \\
\hline
\end{tabular}

Compound 2 was isolated as a yellow oil, had a molecular formula of $\mathrm{C}_{15} \mathrm{H}_{22} \mathrm{O}_{7}$ on the basis of the HR-ESI-MS $\left(\mathrm{m} / \mathrm{z} 315.14283\right.$, calcd. $\left.315.14383[\mathrm{M}+\mathrm{H}]^{+}\right)$. The UV absorption bands at $\lambda_{\max }$ 
224 and $274 \mathrm{~nm}$. The ${ }^{1} \mathrm{H}-\mathrm{NMR}$ spectrum of 2 (Table 2) exhibited an $\mathrm{AA}^{\prime} \mathrm{XX}^{\prime}$ coupling system at $\delta_{\mathrm{H}}$ 7.16-7.26 $(5 \mathrm{H}, \mathrm{m})$, one methxyl at $\delta_{\mathrm{H}} 1.16(3 \mathrm{H}, \mathrm{d}, J=6.3 \mathrm{~Hz})$. The ${ }^{13} \mathrm{C}-\mathrm{NMR}$ spectrum of 2 (Table 2) displayed 15 resonances for six aromatic carbons $\left(\delta_{\mathrm{C}} 140.1,129.3,129.3,127.9,127.9\right.$, and 125.6), two oxymethine carbons $\left(\delta_{\mathrm{C}} 78.6\right.$ and 73.7$)$, one methxyl group $\left(\delta_{\mathrm{C}} 16.5\right)$, and a glucosyl moiety $\left(\delta_{\mathrm{C}}\right.$ $102.9,76.8,76.4,73.5,70.1$, and 61.0). The ${ }^{1} \mathrm{H}$ and ${ }^{13} \mathrm{C}-\mathrm{NMR}$ spectra were similar to those of the known compound 3 [12], expect for the presence an additional glucosyl moiety signals. The major differences in the chemical shifts for $C-1(\Delta C+2.5), C-2(\Delta C+4.3)$, and $C-3(\Delta C-2.6)$ were ascribed to glycosylation, suggesting that the glucosyl moiety was located at $\mathrm{C}-2$. Moreover, the configuration of the anomeric carbon was deduced to be $\beta$ based on the coupling constant of the anomeric proton $\left(\mathrm{H}-1^{\prime \prime}, 7.8 \mathrm{~Hz}\right)$. The small coupling constant ${ }^{3} J_{1,2}(5.1 \mathrm{~Hz})$ of 2 and 3 (Table 2) indicated that 2 and 3 were in the anti-configuration. According to the literatures, the anti-phenylpropane-1,2-diol displayed smaller coupling constants of ${ }^{3} J_{1,2}(4.4-5.4 \mathrm{~Hz})$ than syn-phenylpropane-1,2-diol $\left({ }^{3} J_{1,2}\right.$ 7-8 Hz) [12-18]. Due to the shortage of the sample, the two-dimensional (2D)-NMR experiments were not carried out. On the basis of the above evidence, the planar structure of $\mathbf{2}$ was deduced as anti-1-phenylpropane-1,2-diol-2-O- $\beta$-D-glucopyranoside.

Table $2 .{ }^{13} \mathrm{C}$ - and ${ }^{1} \mathrm{H}-\mathrm{NMR}$ data for compounds 2 and 3 in DMSO- $d_{6}(\delta$ in ppm).

\begin{tabular}{ccccc}
\hline \multirow{2}{*}{ Position } & \multicolumn{2}{c}{3} & \multicolumn{2}{c}{2} \\
\cline { 2 - 5 } & $\delta_{\mathbf{C}}$ & $\delta_{\mathbf{H}}(\boldsymbol{J}$ in Hz) & $\delta_{\mathbf{C}}$ & $\delta_{\mathbf{H}}(\boldsymbol{J}$ in Hz) \\
\hline 1 & 76.1 & $4.48(1 \mathrm{H}, \mathrm{d}, J=5.1)$ & 78.6 & $4.43(1 \mathrm{H}, \mathrm{d}, J=5.1)$ \\
2 & 69.4 & $4.41(1 \mathrm{H}, \mathrm{m})$ & 73.7 & $4.40(1 \mathrm{H}, \mathrm{m})$ \\
3 & 19.1 & $1.08(3 \mathrm{H}, \mathrm{d}, J=6.0)$ & 16.5 & $1.16(3 \mathrm{H}, \mathrm{d}, J=6.3)$ \\
$1^{\prime}$ & 140.3 & & 140.1 & \\
$2^{\prime}, 6^{\prime}$ & 127.8 & $7.15-7.26(5 \mathrm{H}, \mathrm{m})$ & 127.9 & $7.16-7.26(5 \mathrm{H}, \mathrm{m})$ \\
$3^{\prime}, 5^{\prime}$ & 129.3 & $7.15-7.26(5 \mathrm{H}, \mathrm{m})$ & 129.3 & $7.16-7.26(5 \mathrm{H}, \mathrm{m})$ \\
$4^{\prime}$ & 125.5 & $7.15-7.26(5 \mathrm{H}, \mathrm{m})$ & 125.6 & $7.16-7.26(5 \mathrm{H}, \mathrm{m})$ \\
$1^{\prime \prime}$ & $-\mathrm{b}$ & $-\mathrm{b}$ & 102.9 & $4.23(1 \mathrm{H}, \mathrm{d}, J=7.8)$ \\
$2^{\prime \prime}$ & $-\mathrm{b}$ & $-\mathrm{b}$ & 73.5 & $-\mathrm{a}$ \\
$3^{\prime \prime}$ & $-\mathrm{b}$ & $-\mathrm{b}$ & 76.4 & $-\mathrm{a}$ \\
$4^{\prime \prime}$ & $-\mathrm{b}$ & $-\mathrm{b}$ & 70.1 & $-\mathrm{a}$ \\
$5^{\prime \prime}$ & $-\mathrm{b}$ & $-\mathrm{b}$ & 76.8 & $-\mathrm{a}$ \\
$6^{\prime \prime}$ & $-\mathrm{b}$ & $-\mathrm{b}$ & 61.0 & $-\mathrm{a}$ \\
\hline
\end{tabular}

${ }^{\mathrm{a}}$ not assigned; ${ }^{\mathrm{b}}$ no signal.

By comparison of the NMR and MS data with those reported, compounds 3-8 isolated from the flower of $H$. plantaginea were identified as anti-1-phenylpropane-1,2-diol (3) [12], phenethyl-O- $\beta$-D-glucopyranoside (4) [19], phenethanol- $\beta$-gentiobioside (5) [20], phenethyl-Orutinoside (6) [21], (1S,3S)-1-methyl-1,2,3,4-tetrahydro- $\beta$-carboline-3-carboxylic acid (7) [22], and (1R,3S)-1-methyl-1,2,3,4-tetrahydro- $\beta$-carboline-3-carboxylic acid (8) [22], respectively.

\subsection{Biological Activities}

Compounds 1 and 4-6 exhibited moderate activity to that of the standard reference drug, and were tested for their inhibitory activity against ovine COX-1 and COX-2 (Table 3), with $\mathrm{IC}_{50}$ values of 15.5-41.2 and 31.7-45.4 $\mu \mathrm{M}$, while the $\mathrm{IC}_{50}$ values of the positive control celecoxib were 9.0 and $1.0 \mu \mathrm{M}$, respectively. While compounds 1 and 4 were more active against COX 1 (SI values $<<1$ ), compounds 5 and 6 were about equally potent against both COX enzymes with SI values of about 1 .

The antioxidant activity of compounds 1, and 4-6 was measured by the 1,1-diphenyl-2picrylhydrazyl (DPPH) method and the results are summarized in Table 3. Only compound 1 exhibited moderate antioxidant activity, with an $\mathrm{IC}_{50}$ value of $83.2 \mu \mathrm{M}$, while 4-6 showed insignificant activity with $\mathrm{IC}_{50}$ values of 282,257 , and $275 \mu \mathrm{M}$, respectively. The $\mathrm{IC}_{50}$ value of the positive control L-ascorbic 
acid was $33.9 \mu \mathrm{M}$. These compounds may thus, possibly together with further constituents, contribute to the biological activity of $H$. plantaginea.

Table 3. In vitro COX-1/COX-2 inhibition and antioxidant activities of isolated compounds.

\begin{tabular}{ccccc}
\hline \multirow{2}{*}{ Compounds } & \multicolumn{3}{c}{ IC $_{\mathbf{5 0}}(\boldsymbol{\mu M})$} & \multirow{2}{*}{ SI $^{\mathbf{d}}$} \\
\cline { 2 - 4 } & $\mathbf{C O X - 1}^{\mathbf{a}}$ & COX-2 $^{\mathbf{a}}$ & Antioxidant $^{\mathbf{b}}$ & \\
\hline $\mathbf{1}$ & $21.6 \pm 1.2$ & $45.4 \pm 3.3$ & $83.2 \pm 3.0$ & 0.48 \\
$\mathbf{4}$ & $15.5 \pm 0.6$ & $38.2 \pm 3.9$ & $282 \pm 5.2$ & 0.41 \\
$\mathbf{5}$ & $38.4 \pm 1.3$ & $31.7 \pm 2.9$ & $257 \pm 13.8$ & 1.16 \\
$\mathbf{6}$ & $41.2 \pm 1.5$ & $35.4 \pm 1.6$ & $275 \pm 14.8$ & 1.21 \\
celecoxib & $9.0 \pm 0.6$ & $1.0 \pm 0.1$ & $-{ }^{\mathrm{c}}$ & 9.00 \\
L-ascorbic acid & $-{ }^{\mathrm{c}}$ & $-{ }^{\mathrm{c}}$ & $33.9 \pm 1.1$ & $-{ }^{\mathrm{c}}$ \\
\hline
\end{tabular}

\footnotetext{
a Meaning the 50\% inhibition concentration of isolated compounds calculated from regression using five different concentrations $(100,50,25,12.5,6.25 \mu \mathrm{M}){ }^{b}{ }^{\mathrm{b}}$ Meaning the $50 \%$ inhibition concentration of isolated compounds calculated from regression using five different concentrations (500, 200, 100, 50, $25 \mu \mathrm{M}){ }^{c}{ }^{\mathrm{c}}$ Not determined;

d SI (Selectivity Index) $=\mathrm{IC}_{50}(\mathrm{COX}-1) / \mathrm{IC}_{50}(\mathrm{COX}-2)$.
}

\subsection{Chemotaxonomic Significance}

In our present study, eight compounds including one flavanone (1), two phenylpropanoids (2 and $3)$, three phenethanols (4-6), and two $\beta$-carboline alkaloids ( 7 and 8 ) were isolated from the flowers of H. plantaginea. Hostaflavanone A (1) and anti-1-phenylpropane-1,2-diol-2-O- $\beta$-D-glucopyranoside (2) were identified as two new ones, and this is the first report of compounds 3 , and 5-8 from the Liliaceae family. Additionally, the structure types of flavanone and $\beta$-carboline alkaloid from Liliaceae family for the first time.

The phenylpropanoids have been previously isolated from the Hosta species, including trans-p-hydroxy-cinnamic acid from $H$. ventricosa [23], $p$-coumaramide, trans- $N$ - $p$-coumaroyltyramine, and cis- $N$-coumaroyltyramine from $H$. longipes [24], feruloyltyramine, and lyciumide A from $H$. ensata [25]. In addition, the phenethanols 4 and $\alpha$-hydroxyacetovanillone were isolated from $H$. plantaginea and $H$. ventricosa [23], respectively. Thus, compounds 2-6 from $H$. plantaginea, suggesting that their occurrence could be used to verify the chemotaxonomic relationship of $H$. plantaginea and other species of Hosta, and also might sever as valuable chemotaxonomic makers for the identification of $H$. plantaginea. Further comprehensive phytochemical investigations involving an expand series of compounds could help define the chemotaxonomic significance of species belonging to genus Hosta.

\section{Experimental Section}

\subsection{General Procedures}

Optical rotations were measured using a JASCO P-1020 polarimeter (JASCO Corporation, Tokyo, Japan). The UV spectra were recorded in $\mathrm{CH}_{3} \mathrm{OH}$ using a JASCO V-550 UV-VIS spectrophotometer (JASCO Corporation, Tokyo, Japan). ${ }^{1} \mathrm{H}(600 \mathrm{MHz}),{ }^{13} \mathrm{C}(150 \mathrm{MHz})$, DEPT 135 (150 MHz), and 2D $\left({ }^{1} \mathrm{H}^{-1} \mathrm{H}\right.$ COSY, HSQC, and HMBC) NMR spectra were recorded on a Bruker AV 600 spectrometer (Bruker Corporation, Fallanden, Switzerland). HR-ESI-MS was measured on a Waters Synapt G2 TOF mass spectrometer (Waters Corporation, Manchester, UK). Column chromatographies (CCs) were carried out on silica gel (200-300 mesh, Marine Chemical Group Corporation, Qingdao, China) and

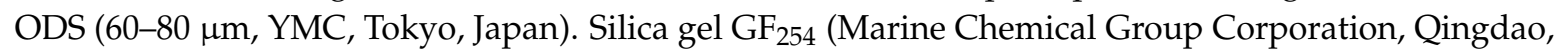
China) was used for analytical TLC. 2,2-Di-phenyl-1-picrylhydrazyl (DPPH) (Sigma Corporation, Ronkonkoma, New York, NY, USA), L-cysteine methyl ester and o-tolyl isothiocyanate (Meilun Biotech. Co. Ltd., Dalian, China), D-glucose, and L-glucose (Energy Chemical, Shanghai, China) were used. COX inhibitor screening assay kit was purchased from Cayman Chemical Company (Ann Arbor, MI, USA). The analytical HPLC was performed on a Shimadzu HPLC system equipped with an LC-20AB pump, and a SPD-20A diode array detector (Shimadzu, Kyoto, Japan), using a Phenomenex Gemini 
C18 column $(5 \mu \mathrm{m}, 4.6 \mathrm{~mm} \times 250 \mathrm{~mm}$, Phenomenex Inc., Los Angeles, CA, USA). The preparative HPLC was performed on a Shimadzu LC-6AD system equipped with an LC-6AD pump and an SPD-M20A detector (Shimadzu, Kyoto, Japan), using an RP-18 column (5 $\mu \mathrm{m}, 21.2 \times 250 \mathrm{~mm}$, Gemini, Phenomenex Inc., Los Angeles, CA, USA; detector set at 220 and $254 \mathrm{~nm}$ ).

\subsection{Plant Materials}

The flowers of Hosta plantaginea (Lam.) Aschers were collected in Shanquan town, Nanchuan district, Chongqing, People's Republic of China, in September 2014, and were identified by one of authors (Guo-yue Zhong). A voucher specimen (no. YZH201409) was deposited at the Research Center of Natural Resources of Chinese Medicinal Materials and Ethnic Medicine, Jiangxi University of Traditional Chinese Medicine, Nanchang, China.

\subsection{Extraction and Isolation}

The air-dried and powdered flowers of $H$. plantaginea $(16.5 \mathrm{~kg}$ ) were extracted three times with $80 \%$ $\mathrm{EtOH}(40 \mathrm{~L})$ by maceration at room temperature for three days. After filtration, combination, and solvent evaporation the residue $(6.60 \mathrm{~kg})$ was dissolved in water and successively partitioned with petroleum ether, ethyl acetate, and $n-\mathrm{BuOH}$ to afford petroleum ether (A, $363 \mathrm{~g})$, ethyl acetate $(\mathrm{B}, 127 \mathrm{~g}), n$ - $\mathrm{BuOH}$ $(\mathrm{C}, 804 \mathrm{~g})$, and water $(5.27 \mathrm{~kg})$ extracts, respectively. The $n-\mathrm{BuOH}$ extract $(760 \mathrm{~g})$ was subjected to HP20 macroporous adsorption resin column chromatography (CC) eluting with $\mathrm{H}_{2} \mathrm{O}, 20 \%, 50 \%$, and $95 \%$ aqueous $\mathrm{EtOH}$ to give four fractions, c1, c2, c3, and c4, respectively. Fr. c2 (32.8 g) was subjected to MCI $\mathrm{CC}$ using a $\mathrm{EtOH} / \mathrm{H}_{2} \mathrm{O}$ gradient elution $(10 \%, 20 \%, 30 \%$, and $95 \%$ ) to give four fractions (c21 to c2d). The subfraction $\mathrm{c} 2 \mathrm{c}(6.02 \mathrm{~g})$ was applied to silica gel CC eluting with dichloromethane- $\mathrm{CH}_{3} \mathrm{OH}(5: 1,3: 1$, $1 ; 1,0: 100, v / v)$ to afford four subfractions (c2c1-c2c4). c2c2 (1.04 g) was purified by pre-HPLC eluting with $\mathrm{CH}_{3} \mathrm{OH} / \mathrm{H}_{2} \mathrm{O}(v / v, 35: 65$, flow rate: $10 \mathrm{~mL} / \mathrm{min})$ to afford compound 1 (53.7 $\left.\mathrm{mg}, \mathrm{t}_{\mathrm{R}} 22.7 \mathrm{~min}\right)$. The subfraction $\mathrm{c} 2 \mathrm{~b}(15.1 \mathrm{~g})$ was applied to polyamide $\mathrm{CC}$ using a $\mathrm{EtOH} / \mathrm{H}_{2} \mathrm{O}$ gradient elution $(10 \%, 20 \%$, and $95 \%$ ) to afford five subfractions ( $\mathrm{c} 2 \mathrm{~b} 1-\mathrm{c} 2 \mathrm{~b} 5)$. The subfraction $\mathrm{c} 2 \mathrm{~b} 1(7.12 \mathrm{~g})$ was applied to silica gel $\mathrm{CC}$ eluting with dichloromethane- $\mathrm{CH}_{3} \mathrm{OH}(10: 1,5: 1,1: 5, v / v)$ to afford four subfractions (c2b11-c2b14). c2b11 (1.81 g) was purified by pre-HPLC eluting with $\mathrm{CH}_{3} \mathrm{CN} / \mathrm{H}_{2} \mathrm{O}(v / v, 20: 80$, flow rate: $2 \mathrm{~mL} / \mathrm{min})$ to afford compounds 2 (1.0 mg, $\left.\mathrm{t}_{\mathrm{R}} 15.0 \mathrm{~min}\right), 3\left(0.7 \mathrm{mg}\right.$, $\left.\mathrm{t}_{\mathrm{R}} 25.3 \mathrm{~min}\right)$, and 4 (1.45 g, $\left.\mathrm{t}_{\mathrm{R}} 17.2 \mathrm{~min}\right)$. c2 $2 \mathrm{~b} 12$ (1.19 g) was purified by pre-HPLC eluting with $\mathrm{CH}_{3} \mathrm{OH} / \mathrm{H}_{2} \mathrm{O}(v / v, 30: 70$, flow rate: $10 \mathrm{~mL} / \mathrm{min}$ ) to afford compound6 $6\left(1.10 \mathrm{~g}, \mathrm{t}_{\mathrm{R}} 31.0 \mathrm{~min}\right)$. The subfraction $\mathrm{c} 2 \mathrm{a}(8.05 \mathrm{~g})$ was applied to silica gel CC eluting with dichloromethane $/ \mathrm{CH}_{3} \mathrm{OH}(1: 1,1: 3,1: 10, v / v)$ to afford three subfractions (c2a1-c2a3). c2a1 (3.89 g) was subjected to Sephadex LH-20 CC eluting with $\mathrm{CH}_{3} \mathrm{OH}$ to afford three subfractions (c2a11-c2a13). c2a12 (2.59 g) was purified by pre-HPLC eluting with $\mathrm{CH}_{3} \mathrm{OH} / \mathrm{H}_{2} \mathrm{O}(v / v, 25: 75$, flow rate: $10 \mathrm{~mL} / \mathrm{min})$ to afford compounds 5 (329 mg, $\left.\mathrm{t}_{\mathrm{R}} 32.8 \mathrm{~min}\right), 7$ (1.9 mg, $\left.\mathrm{t}_{\mathrm{R}} 23.2 \mathrm{~min}\right)$, and $8\left(1.4 \mathrm{mg}, \mathrm{t}_{\mathrm{R}} 27.3 \mathrm{~min}\right)$.

\subsection{Acid Hydrolysis and HPLC Analysis}

The absolute configurations of the sugar moieties in the structures were determined by the previously described method with minor modifications [9]. Compound $\mathbf{1}(3 \mathrm{mg})$ was hydrolyzed with $2 \mathrm{~mL}$ of $2 \mathrm{M} \mathrm{HCl}$ for $3 \mathrm{~h}$ at $90{ }^{\circ} \mathrm{C}$. The mixture was evaporated to dryness in vacuo, and the residue was dissolved in $\mathrm{H}_{2} \mathrm{O}$ and extracted with $\mathrm{CHCl}_{3}$. After the aqueous layer was dried in vacuo, the residue was dissolved in pyridine $(1 \mathrm{~mL})$ containing L-cysteine methyl ester $(1 \mathrm{mg})$ and heated at $60{ }^{\circ} \mathrm{C}$ for $1 \mathrm{~h}$. $o$-Tolyl isothiocyanate $(5 \mu \mathrm{L})$ was added, and the mixture was heated at $60{ }^{\circ} \mathrm{C}$ for $1 \mathrm{~h}$ and directly analyzed by HPLC. Analytical HPLC was performed on a reversed-phase C18 column $(5 \mu \mathrm{m}$, $4.60 \times 250 \mathrm{~mm}$; Intertsutain, Shimadzu) at $30^{\circ} \mathrm{C}$ with isocratic elution using $25 \% \mathrm{CH}_{3} \mathrm{CN}$ containing $0.1 \%$ formic acid for $40 \mathrm{~min}$ at a flow rate $0.8 \mathrm{~mL} / \mathrm{min}$. The peaks were detected with a UV detector at $250 \mathrm{~nm}$. The standard monosaccharides, D-glucose, and L-glucose, were subjected to the same process. 


\subsection{In Vitro COX-1 and COX-2 Inhibitory Assay}

Inhibitory activities of the compounds towards COX-1 and COX-2 activity was determined using colorimetric COX (ovine) inhibitor screening assay kit (Cayman, no. 760111) following the manufacturer's instructions, using celecoxib as a positive control [26]. The 50\% inhibitory concentration $\left(\mathrm{IC}_{50}\right)$ values were calculated from the concentration-inhibition response curve.

\subsection{Antioxidant Assay}

DPPH radical-scavenging activity of the sample was measured as previously described with minor modifications [27]. In a 96-well microplate, $150 \mu \mathrm{L}$ of DPPH solution $(200 \mu \mathrm{M})$ was added to $50 \mu \mathrm{L}$ of the test sample in methanol at different concentrations. The OD values of the reaction mixtures was recorded at $517 \mathrm{~nm}$ using a Multiskan Go (Thermo Fisher Scientific, Inc., Waltham, MA, USA) for 40 min at $30^{\circ} \mathrm{C}$. The DPPH radical scavenging activity was calculated by the following equation: $\mathrm{DPPH}$ scavenging activity $\%=\left(A_{\text {sample }}-A_{\text {blank }}\right) / A_{\text {control }} \times 100$, where $A_{\text {sample }}$ represents the absorbance of sample and DPPH, $\mathrm{A}_{\text {blank }}$ represents the absorbance of sample and $\mathrm{CH}_{3} \mathrm{OH}, \mathrm{A}_{\text {control }}$ represents the absorbance of $\mathrm{DPPH}$ and $\mathrm{CH}_{3} \mathrm{OH}$. $\mathrm{IC}_{50}$ value was calculated as the concentration required to scavenge $50 \%$ DPPH free radicals and was obtained by plotting the DPPH-scavenging percentage of each sample against the sample concentration. L-ascorbic acid was used as the positive control in this experiment. All tests were run in triplicate, and values obtained from experiments were averaged.

\section{Conclusions}

In summary, one new flavanone (1) and one new phenylpropanoid (2), together with six known ones, one phenylpropanoid (3), three phenethanols (4-6), and two $\beta$-carboline alkaloids (7 and 8), were isolated from the flowers of $H$. plantaginea. This is the first report of compounds $\mathbf{3}$ and 5-8 from the Liliaceae family. Additionally, the structure types of flavanone and $\beta$-carboline alkaloid from the Liliaceae family for the first time. Moreover, compounds 2-6 from H. plantaginea suggest that their occurrence could be used to verify the chemotaxonomic relationship of $H$. plantaginea and other species of Hosta, and also might serve as valuable chemotaxonomic makers for the identification of H. plantaginea. The cyclooxygenases' (COX-1 and COX-2) inhibition and antioxidant activities of compounds 1 and 4-6 were investigated, and they showed moderate cyclooxygenase inhibition activities. Moreover, only compound 1 exhibited moderate antioxidant activity, with an $\mathrm{IC}_{50}$ value of $83.2 \mu \mathrm{M}$, while 4-6 showed insignificant activity with $\mathrm{IC}_{50}$ values of 282,257 , and $275 \mu \mathrm{M}$, respectively. These compounds may, possibly together with further constituents, contribute to the biological activity of H. plantaginea.

Supplementary Materials: The ${ }^{1} \mathrm{H}-\mathrm{NMR},{ }^{13} \mathrm{C}-\mathrm{NMR}$, DEPT- $135,{ }^{1} \mathrm{H}-{ }^{1} \mathrm{H}$ COSY, HSQC, and HMBC spectra of 1 and 2 are available as supplementary materials available online.

Acknowledgments: This work was financially supported by grants from the National Natural Science Foundation of China (No. 81503357), the Natural Science Foundation of Jiangxi Province (No. 20161BAB215209 and 20171BBH80026), the China Postdoctoral Science Foundation (No. 2016M600514), and the Research Project of Jiangxi Health Department (No. 2016A058).

Author Contributions: The list authors contributed to this work as follows: L.Y. and J.-W.H. conceived and designed the experiments; S.-T.J., Q.-G.Z., L.Y., and J.-W.H. performed the experiments and analyzed the data; L.Y. and J.-W.H. wrote the paper; and G.-Y. Z. and J.-W.H. acquired funding for the research. All authors read and approved the final manuscript.

Conflicts of Interest: The authors declare no conflict of interest.

\section{References}

1. Liu, J.X.; Zhao, C.H.; Liu, X.R.; Xi, Y.Z.; Zhang, Y.L. Pollen morphology of Hosta Tratt. in China and its taxonomic significance. Plant Syst. Evol. 2011, 294, 99-107. [CrossRef]

2. State Administration of Traditional Chinese Medicine. Chinese Materia Medica; Shanghai Science and Technology Press: Shanghai, China, 1999; Volume VIII, pp. 107-108. 
3. He, J.W.; Yang, L.; Zhong, G.Y. Research progress in chemical constituents, pharmacological activities, clinical practices and quality control of folk medicine Hosta plantaginea. Chin. Tradit. Herb. Drugs 2016, 47, 4295-4300.

4. Wang, Q.H.; Han, J.J.; Bao, B.Y. Antibacterial effects of two monoterpene glycosides from Hosta plantaginea (lam.) Aschers. J. Food Biochem. 2017, 41, e12320. [CrossRef]

5. He, J.W.; Yang, L.; Zhu, J.X.; Wang, X.M.; Zhou, Z.R.; He, W.W.; Zhong, G.Y. Comparison of anti-inflammatory effects and HPLC detection on different extracts from the flower of Hosta plantaginea in mice. J. Jiangxi Norm. Univ. (Nat. Sci.) 2016, 40, 183-185.

6. Wang, Y.H.; Zhang, Z.K.; Yang, F.M.; Sun, Q.Y.; He, H.P.; Di, Y.T.; Mu, S.Z.; Lu, Y.; Chang, Y.; Zheng, Q.T.; et al. Benzylphenethylamine Alkaloids from Hosta plantaginea with inhibitory activity against tobacco mosaic virus and acetylcholinesterase. J. Nat. Prod. 2007, 70, 1458-1461. [CrossRef] [PubMed]

7. Xie, H.X.; Zhang, J.H.; Zhang, H.G.; Xue, P.F. Studies on chemical constituents from Hosta plantaginea (Lam.) Asehers, a Mongolia medieine. Chin. Pharm. J. 2009, 44, 733-735.

8. Mimaki, Y.; Kameyama, A.; Kuroda, M.; Sashida, Y.; Hirano, T.; Oka, K.; Koike, K.; Nikadio, T. Steroidal glycosides from the underground parts of Hosta plantainea var. Japonica and their cytostatic activity on leukamia HL-60 cells. Phytochemistry 1997, 44, 305-310. [CrossRef]

9. Li, B.; Ni, Y.; Zhu, L.J.; Wu, F.B.; Yan, F.; Zhang, X.; Yao, X.S. Flavonoids from matteuccia struthiopteris and their anti-influenza virus (H1N1) activity. J. Nat. Prod. 2015, 78, 987-995. [CrossRef] [PubMed]

10. Bahuguna, R.P.; Jangwan, J.S.; Kaiya, T.; Sakakibara, J. Puddumin A, a new flavanone glucoside from Prunus cerasoides. J. Nat. Prod. 1987, 50, 232-234. [CrossRef]

11. Hanáková, Z.; Hošek, J.; Kutil, Z.; Temml, V.; Landa, P.; Vaněk, T.; Schuster, D.; Dall’Acqua, S.; Cvačka, J.; Polansky, O.; Šmejkal, K. Anti-inflammatory activity of natural geranylated flavonoids: Cyclooxygenase and lipoxygenase inhibitory properties and proteomic analysis. J. Nat. Prod. 2017, 80, 999-1006. [CrossRef] [PubMed]

12. Andreu, C.; Olmo, M. Potential of some yeast strains in the stereoselective synthesis of $(R)$-(-)-phenylacetylcarbinol and (S)-(+)-phenylacetylcarbinol and their reduced 1,2-dialcohol derivatives. Appl. Microbiol. Biotechnol. 2014, 98, 5901-5913. [CrossRef] [PubMed]

13. Hao, B.; Gunaratna, M.J.; Zhang, M.; Weerasekara, S.; Seiwald, S.N.; Nguyen, V.T.; Meier, A.; Hua, D.H. Chiral-substituted poly- $N$-vinylpyrrolidinones and bimetallic nanoclusters in catalytic asymmetric oxidation reactions. J. Am. Chem. Soc. 2016, 138, 16839-16848. [CrossRef] [PubMed]

14. Wu, S.K.; Chen, Y.Z.; Xu, Y.; Li, A.T.; Xu, Q.S.; Glieder, A.; Li, Z. Enantioselective trans-dihydroxylation of aryl olefins by cascade biocatalysis with recombinant Escherichia coli coexpressing monooxygenase and epoxide hydrolase. ACS Catal. 2014, 4, 409-420. [CrossRef]

15. Kingsbury, C.A.; Cowles, C.R. Conformations of vicinal diesters. J. Org. Chem. 1975, 40, 1302-1308. [CrossRef]

16. Kihumbu, D.; Stillger, T.; Hummel, W.; Liese, A. Enzymatic synthesis of all stereoisomers of 1-phenylpropane-1,2-diol. Tetrahedron Asymmetry 2002, 13, 1069-1072. [CrossRef]

17. Brambilia, U.; Nasini, G.; Pava, O.V. Secondary mold metabolites, part 49. isolation, structural elucidation, and biomimetic synthesis of trametol, a new 1-arylpropane-1,2-diol produced by the fungus Trametes sp. J. Nat. Prod. 1995, 58, 1251-1253. [CrossRef]

18. Mayorga, H.; Knapp, H.; Winterhalter, P.; Duque, C. Glycosidically bound flavor compounds of cape gooseberry (Physalis Peruviana L.). J. Agric. Food Chem. 2001, 49, 1904-1908. [CrossRef] [PubMed]

19. Liu, J.; Li, C.J.; Yang, J.Z.; Ma, J.; Zhang, D.M. Chemical constituents from stems of Clausena lansium. Chin. Tradit. Herb. Drugs 2016, 47, 32-37.

20. Ma, S.J.; Mizutani, M.; Hiratake, J.; Hayashi, K.; Yagi, K.; Watanabe, N.; Sakata, K. Substrate specificity of $\beta$-primeverosidase, a key enzyme in aroma formation during oolong tea and black tea manufacturing. Biosci. Biotechnol. Biochem. 2001, 65, 2719-2729. [CrossRef] [PubMed]

21. Hamerski, L.; Bomm, M.D.; Silva, D.H.; Young, M.C.M.; Furlan, M.; EBerlin, M.N.; Castro-Gamboa, I.; Cavalherio, A.J.; Bolzani, V.S. Phenylpropanoid glucosides from leaves of Coussarea hydrangeifolia (Rubiaceae). Phytochemistry 2005, 66, 1927-1932. [CrossRef] [PubMed]

22. Li, G.Q.; Deng, Z.W.; Li, J.; Fu, H.Z.; Lin, W.H. Chemical constituents from starfish Asterias rollestoni. J. Chin. Pharm. Sci. 2004, 13, 81-86.

23. Yang, S.X.; Zhao, F.W.; Wang, H.; Huang, Q.Q.; Xu, J.J.; Wang, Y.H.; Long, C.L. Chemical constituents of Hosta ventricosa, an ornamental medicinal plant. J. Yunnan Agric. Univ. 2011, 26, 662-667. 
24. Kim, C.S.; Kim, K.Y.; Lee, K.R. Phytochemical constituents of the leaves of Hosta longipes. Nat. Prod. Sci. 2014, 20, 86-90.

25. Liu, H.X.; Sun, Q.Y.; Yang, F.M.; Zhao, F.W.; Wang, Y.H.; Long, C.L. A new sesquiterpene lactone from H. ensata. Chem. Nat. Compd. 2012, 48, 580-582. [CrossRef]

26. Ochieng, G.O.; Opiyo, S.A.; Mureka, E.W.; Ishola, I.O. Cyclooxygenase inhibitory compounds from Gymnosporia heterophylla aerial parts. Fitoterapia 2017, 119, 168-174. [CrossRef] [PubMed]

27. Zhou, J.T.; Li, C.Y.; Wang, C.H.; Wang, Y.F.; Wang, X.D.; Wang, H.T.; Zhu, Y.; Jiang, M.M.; Gao, X.M. Phenolic compounds from the roots of Rhodiola crenulata and their antioxidant and inducing IFN- $\gamma$ production activities. Molecules 2015, 20, 13725-13739. [CrossRef] [PubMed]

Sample Availability: Not available.

(C) 2017 by the authors. Licensee MDPI, Basel, Switzerland. This article is an open access article distributed under the terms and conditions of the Creative Commons Attribution (CC BY) license (http://creativecommons.org/licenses/by/4.0/). 